\title{
Responses of Strawberry Species and Cultivars to the Root-lesion and Northern Root-knot Nematodes
}

\author{
Jack Pinkerton ${ }^{1}$ and Chad E. Finn ${ }^{2}$ \\ U.S. Department of Agriculture-Agricultural Research Service, Horticultural \\ Crops Research Laboratory, Northwest Center for Small Fruit Research, \\ Corvallis, OR 97330
}

Additional index words. Fragaria $\times$ ananassa, Fragaria chiloensis, Fragaria virginiana, fruit breeding, germplasm. Meloidogyne hapla, Pratylenchus penetrans, resistance, tolerance

\begin{abstract}
The relative susceptibility of $\mathbf{4 4}$ genotypes of wild Fragaria L. and commercial cultivars of strawberry Fragaria xananassa Duch. to Meloidogyne hapla Chitwood and Pratylenchus penetrans (Cobb) Filipjev \& Shuurmans Stekhoven was evaluated in the greenhouse. Eleven genotypes were highly resistant to populations of M. hapla from Washington State and Oregon, with Rf values (initial nematode density/final population density) less than 0.5 . However, root growth of most genotypes, including resistant genotypes, was reduced by $M$. hapla. Thirteen genotypes were ranked more resistant to $P$. penetrans than $F$. xananassa 'Totem', a susceptible cultivar. Root growth of most genotypes was not affected by $P$. penetrans under these experimental conditions. We conclude that commercial cultivars and wild Fragaria genotypes can provide a readily exploitable source of resistance to $M$. hapla. Conversely, sources of resistance to $P$. penetrans were uncommon in the germplasm evaluated. The $F$. xananassa cultivars, which already have commercially important characteristics, appear to be a better source of resistance for both nematode species than the wild, unimproved germplasm.
\end{abstract}

Plant-parasitic nematodes can affect the growth and development of strawberry resulting in economic loss. Genera of phytonematodes modify root growth and function (Meloidogyne, Xiphinena, and Longidorus), induce root necrosis (Pratylenchus), deform and stunt leaves and shoots (Aphelenchoides), vector NEPO viruses (Xiphimena, and Longidorus), and interact with soilborne fungal and bacterial pathogens (Pratylenchus and Meloidogyne) (Brown et al, 1993; Esnard and Zuckerman, 1998). Currently, phytonematodes are controlled by preplant fumigation and/or post-plant applications of nonfumigant nematicides. However, these management options may not be available in the future. Methyl bromide, the most effective fumigant, is being phased out of use because of regulations that document its role in depletion of the ozone layer (Clean Air Act, 1990). Methyl bromide will be available in limited quantities after 2005 only for approved critical uses that do not have technically or economically feasible alternatives. Registration and use of many nematicides in minor crops also may be limited because of provisions in the Food Quality Protection Act (1996). The introduction of strawberry cultivars that are tolerant and/or resistant to phytonematodes should decrease the reliance on nematicides to maintain the productivity of plants in nematode-infested soils.

Received for publication 25 Sept. 2003. Accepted for publication 20 May 2004. This research was partially funded by a USDA-ARS Germplasm Evaluation Grant. We gratefully acknowledge the assistance of Tim Lair and Ted Mackey.

'Research plant pathologist.

${ }^{2}$ Research geneticist.
Meloidogyne hapla Chitwood (northern root-knot nematode) and Pratylenchus penetrans (Cobb) Filipjev \& Shuurmans Stekhoven (root-lesion nematode) are important pests in strawberry production worldwide (Brown et al. 1993; Esnard and Zuckerman, 1998). Meloidogyne hapla second-stage juveniles penetrate the tips of young roots where they cause small galls and the proliferation of adventitious rootlets (Edwards et al., 1985). The physiology and water relations of infected plants are disrupted and may result in severe stunting in sandy soils. Pratylenchus penetrans is an endoparasite that migrates through and feeds in the root cortex (Townshend, 1963a). These activities kill the surrounding root tissues, which become visible as discrete necrotic lesions. When high $P$. penetrans population densities are present, the lesions may coalesce and girdle the roots. The above ground symptoms of infected strawberry plants are similar for both nematode species; stunting, reduced runner production, depressed yields, and shortened life of the planting. In addition to the direct damage $P$. penetrans and $M$. hapla cause, both species have been implicated in disease complexes affecting strawberry (Abu-Gharbieh et al, 1962; Kurppa and Vrain, 1989; Martin, 1988; Szczygiel and Profic-Alwasiak, 1989).

Plant resistance is the ability of a plant to suppress nematode development and reproduction (Roberts, 2002). Plant tolerance is the ability of a plant to withstand nematode infection without the loss of plant growth or productivity (Roberts, 2002). Host plant resistance and/or tolerance have been proven a cost-effective strategy for managing plant-parasitic nematode that affect agronomic and horticultural crops (Young, 1998). This approach has potential for management of nematode damage in strawberry. Orchard and Andrichem (1961) observed differential root galling and egg mass production in eleven Fragaria species and subspecies that were planted in soil infested with $M$. hapla. Similarly, Dickstein and Krusberg (1978) reported that 33 strawberry cultivars differed considerably in their galling response to $M$. hapla. Based on the fresh biomass of 46 strawberry cultivars in several greenhouse studies, 'Earliglow' (Edwards, et al. 1985) and 'Glima' and 'Senga Sengana' (Szczygiel, 1981a) were tolerant or highly resistant to M. hapla. Szczygiel (1981b) also found 'Senga Sengana' to be the most resistant and tolerant to $P$. penetrans among 28 cultivars evaluated. Potter and Dale (1994; Dale and Potter, 1998) reported resistance and tolerance to P. penetrans among Fragaria chiloensis (L.) Duch. and $F$. virginiana Duch. genotypes and $F$. xananassa cultivars. Based on their work with a limited number of genotypes, they concluded that resistance to $P$. penetrans can be increased in cultivated strawberries by introducing wild germplasm and that further screening of Fragaria germplasm is warranted. Moreover, research data cited above suggests that screening for resistance to $M$. hapla should be profitable.

Hancock et al. (2001a, 2002) have identified a supercore group of native $F$. virginiana and $F$. chiloensis clones that represent the broad distribution of the octoploid species in North and South America. Further, they have focused various Fragaria germplasm evaluation projects on this supercore (Hancock et al. 2001b).

The objective of this study was to evaluate an elite group of strawberry accessions for resistance and tolerance to M. hapla and P.penetrans. Accessions were primarily from the supercore (Hancock et al, 2001a) of subspecies of F. chiloensis (L.) Miller and $F$. virginiana Miller along with $F$. xananassa cultivars that are important in production areas of North America

\section{Materials and Methods}

Native octoploid strawberries were propagated vegetatively at the USDA-ARS Horticultural Crops Research Laboratory, Corvallis, Ore. Plants not available at the HCRL were obtained from the USDA-ARS National Clonal Germplasm Repository in Corvallis and Jim Hancock at Michigan State University, East Lansing. Several cultivars were obtained as bare root plants from commercial nurseries. Plants of each genotype were kept in a greenhouse under long day conditions (16-h photoperiod) with $24{ }^{\circ} \mathrm{C}$ day and $18{ }^{\circ} \mathrm{C}$ night temperatures. In March through April, runners were pegged into four inch pots containing about $800 \mathrm{~g}$ of steam pasteurized sandy soil (1:2 by volume, washed sand and Willamette loam). Once established, the rooted daughter plants were cut from the mother plant and grown in the greenhouse.

Genotypes varied in initiation of runners and development of daughter plants, with some genotypes requiring an additional month to reach the size desired for the experiment. 
Because of differential development of plants and the space constraints in extracting nematodes from soil and root tissue, genotypes were divided into three groups based on plant development to obtain plants of similar size for each run. Those genotypes that produced runners and rooted the quickest were screened in the first run, while the slower growing genotypes were included in the third run.

The population of $P$. penetrans used in the study was collected in a peppermint (Mentha piperita L. 'Todd') field in Harrisburg, Ore. Nematodes were extracted from peppermint roots and used to infest pasteurized loam: sand containing 'Totem' strawberry plants in greenhouse pot cultures (Forge et al. 2000). After nine months, nematodes were collected from the strawberry roots and used to infect new nematode-free peppermint plants, which served as stock culture for all experiments. Populations of $M$. hapla (Mh) were collected from vineyards in Dundee, Ore. (MhO), and Benton City, Wash. (MhW). A tomato ( $L y$ coperisicon esculentum Mill. 'Early Girl'), was planted in the vineyard soil mixed with loam:sand. After 6 months, egg masses were collected from tomato roots and used to infect 'Totem' strawberry greenhouse cultures. Specimens of female and second-stage juvenile (J2) nematodes were collected from the strawberry roots and examined to verify that the population was solely $M$. hapla. Stock cultures of M. hapla on tomato were started with egg masses collected from strawberry roots.

Nematodes used to infect the Fragaria genotypes were extracted from the roots of stock cultures immediately before they were needed. Peppermint roots were washed free of soil and placed under intermittent mist to extract P. penetrans (Ayoub, 1981). Nematodes were collected daily and stored in water two days or less at $4{ }^{\circ} \mathrm{C}$ before infesting soil. Eggs of $M$. hapla were extracted from roots of tomato cultures using a $\mathrm{NaOCl}$ method (Hussey and Barker, 1973). The density of nematodes or eggs in the suspensions used to infest the soil was adjusted to $75 / \mathrm{mL}$ for $P$. penetrans and $200 \mathrm{eggs} / \mathrm{mL}$ for $M$. hapla. Four holes $(1 \mathrm{~cm}$ diameter $\times 5 \mathrm{~cm}$ ) were made around the crown of each plant, $5 \mathrm{~mL}$ of the nematode suspension was pipetted into each hole, and the holes were filled with soil mix. Infestation densities were 1500 P. penetrans per pot (2/g soil) or 4000 $M$. hapla eggs per pot (5/g soil).

Twenty-four plants of each genotype were selected for uniformity and three plants of similar size were selected for each replication. Two plants were infested with either P. penetrans or M. hapla, while the third plant in the replication was a noninfested control. Experimental design was randomized block with eight replications. Plants infested with $M$. hapla, P. penetrans and noninfested controls were blocked in each replication and separated with fiberglass barriers to prevent cross-contamination. The experiment was conducted in a greenhouse with supplementary light (16-h photoperiod) and temperature maintained between 18 to 26 ${ }^{\circ} \mathrm{C}$. Plants were fertilized with 15-5-15 CalMag (Scott Co., Maryville, Ohio) biweekly. The three groups or runs of genotypes were infested with nematodes at 2-week intervals; on 22 June, 6 July, and 20 July 2000 . Because the mist-chamber malfunctioned in the first run and $P$. penetrans extracted from the roots were lost, these genotypes were evaluated again in 2001. Plants were infested on 26 July 2001 for run 4. Plants were not available for RH 30, NC 95-19-1, CFRA 440, and CFRA 368 genotypes, so they were not evaluated for response to $P$. penetrans. Those genotypes that showed resistance to $\mathrm{MhO}$ in 2000, were evaluated with the MhW population in July 2001. 'Totem' was selected as the standard in each run because it has been shown to be good host for M. hapla (Pinkerton, unpublished data) and $P$. penetrans (Forge et al., 2000) and it accounts for $90 \%$ of strawberry production in the Pacific Northwest. At least two other genotypes were repeated in two more runs. 'Early Girl' tomatoes served as a control for viability of M. hapla inoculum in each run.

Twelve weeks after infestation of the soil, plants were cut off at the soil line, the shoots were oven-dried at $50{ }^{\circ} \mathrm{C}$, and the tissue weighed. At this time, the root system was shaken carefully and brushed to remove soil. A 100-g soil sample from each pot was processed by the Baermann funnel method (Townshend, 1963b) to extract the vermiform stages of both nematode species. Initially the roots were washed free of soil by submerging them in water and then carefully washing them in a gentle stream of water. Root systems of plants infected with $P$. penetrans were placed under intermittent mist for $7 \mathrm{~d}$ to extract the nematodes. Roots infected with $M$. hapla were inspected under a dissecting microscope for the presence of galls. A gall rating was assigned to each root system; $0=$ no galls, $1=1$ to 2 galls, $2=3$ to $10,3=11$ to $30,4=31$ to 100 , and $5=>100$ galls (Taylor and Sasser, 1978). Each root system was then cut into 2 to $4 \mathrm{~cm}$ pieces and eggs were extracted in $\mathrm{NaOCl}$ as described by Hussey and Barker (1973). Nematode eggs collected in a $28-\mu$ sieve were rinsed into a beaker from which a 1-mL sample was drawn to count the eggs. After extracting the nematodes or eggs, roots were oven-dried at $50{ }^{\circ} \mathrm{C}$ and the tissue weighed.

Plant resistance was expressed the reproductive factor $(\mathrm{Rf}=$ final population density [eggs and/or vermiform stages]/initial nematode population density). To standardize the data between the runs, data also were expressed as the relationship of the $\mathrm{Rf}$ value of each nematode species on each genotype to its $\mathrm{Rf}$ value on 'Totem' in each replication (genotype Rf/Totem Rf). The mean gall rating for $M$. hapla and the number of $P$. penetrans/g root also were calculated. Pratylenchus penetrans $/ \mathrm{g}$ root was transformed, $\log _{10}(\mathrm{x}+1)$, before statistical analysis. Plant tolerance was expressed as the ratio of plant dry weights between paired infected and noninfected plants in each replication (infected weight/noninfected weight). Tolerance ratio values were calculated for root and total plant dry weights. Model variance components were estimated using ANOVA procedures and means separated by Fisher's protected LSD (Statgraphics, version 3, Manugistics Inc., Rockville, Md., 1997).

\section{Results}

Meloidogyne hapla trials. Gall rating, Rf $\times$ 'Totem', and root and shoot tolerance ratio values were not different $(P \leq 0.05)$ between the $\mathrm{MhO}$ and $\mathrm{MhW}$ populations. Therefore, data were combined for analysis of variance.

Fragaria subspecies segregated to three groups by root galling (Table 1$) ; F$. virginiana subsp. virginiana (south) and $F$. $\times$ ananassa had the lowest gall ratings $(P \leq 0.001), F$. virginiana subsp. virginiana (north), F. chiloensis subsp. chiloensis, and $F$. virginiana subsp. glauca had intermediate ratings, and $F$. chiloensis subsp. pacifica, $F$. virginiana subsp. platypetala, and F. chiloensis f. patagonica subsp. chiloensis had the most galling. Gall rating values were similar between runs for genotypes tested in multiple runs. For example, gall rating values for 'Totem' ranged between 4.25 and 5.0. Fifteen genotypes infected with $\mathrm{MhO}$ had gall ratings $<1.0$ and of those genotypes retested with MhW, only NC 96-48-1, JP 95-1-1, and 'Jewel' had gall ratings $>1.0$.

Nematode reproduction on Fragaria genera corresponded to gall ratings (Table 1). The Rf values of genera segregated to three groups in which $F$. virginiana subsp. glauca and $F$. virginiana subsp. virginiana (south) had the lowest values and $F$. virginiana subsp. virginiana (north) and $F$. chiloensis subsp. pacifica had the greatest Rf values. 'Totem' was among the most susceptible genotypes with mean Rf values greater $(P \leq 0.01)$ for MhW (52.9) than for MhO (15.1). However, reproduction was not different between $M$. hapla populations for most genotypes. Of the 14 genotypes that had mean $\mathrm{Rf}$ values $\leq 1.0$ with MhO, 3 had $\mathrm{Rf}$ values $>3$ when retested with MhW and of these only JP 95-1-1 had a significantly greater $(P \leq 0.01) \mathrm{Rf}$ value $(12.6)$ with MhW. After standardizing $\mathrm{Rf}$ values of genotypes relative to 'Totem', genotypes with Rf values $<1.0$ also were the most resistant compared to 'Totem' with $\mathrm{Rf} \times \mathrm{T}$ values $<0.1$. Mean $\mathrm{Rf}$ values for 'Early girl' tomato ranged from 76 to 233 among runs.

Root biomass of 20 genotypes was reduced significantly $(P<0.05)$ in plants infected with M. hapla compared to noninfected control plants (Table 1); the mean reduction of all genotypes was $69 \%$ (tolerance ratio $=0.69$ ). Root growth of 'Totem' was reduced 10 to $33 \%$ in the four runs, while root mass was reduced $>25 \%$ in 24 genotypes. However, the reduction in root mass was not correlated $(P$ $\leq 0.05$ ) with gall rating, $\mathrm{Rf}$ value, or eggs/g root (data not presented). Total plant weights of 15 genotypes was reduced $(P \leq 0.05)$ for plants infected with $M$. hapla compared with noninfected plants (Table 1).

Pratylenchuspenetranstrials. The Rf values ranged from 0.06 to 1.32 (Table 2). 'Totem' had an intermediate $\mathrm{Rf}$ value (0.33) among the genotypes with only 13 genotypes having the $\operatorname{Rf} \times$ 'Totem' values $<1.0$. The $\mathrm{Rf}$ values of genotypes tested in more than one run did not differ $(P=0.093)$. Nematodes per gram root ranged from 18 to 1400 , with 'Totem' intermediate (95.4). Among the eight taxon groupings, reproduction of $P$. penetrans was the greatest 
$(P \leq 0.001)$ on $F$. chiloensis subsp. pacifica and $F$. virginiana subsp. platypetala and the lower for all other Fragaria taxa (Table 2). Fragaria chiloensis subsp. pacifica and $F$. virginiana subsp. platypetala genotypes had the greatest nematodes/g root $(P \leq 0.001)$, Fragariachiloen- sis f. patagonica subsp. chiloensis genotypes were intermediate, and the other genera had the fewest nematodes in the roots.

Table 1. Taxa and genotype means for gall rating, reproductive factor $(\mathrm{Rf})^{2}$, reproductive factor of genotypes compared to 'Totem', and tolerance ratio values of root and whole plant biomass of strawberry genotypes infected with Meloidogyne hapla grown in greenhouse pots for 12 weeks.

\begin{tabular}{|c|c|c|c|c|c|c|c|}
\hline Species & Taxon & $\begin{array}{c}\text { No. of } \\
\text { genotypes }\end{array}$ & Rf & $\begin{array}{c}\operatorname{Rf} x \\
\text { Totem }\end{array}$ & $\begin{array}{c}\text { Gall } \\
\text { rating }^{\mathrm{x}}\end{array}$ & & \\
\hline F. chiloensis subsp. $f$. chiloensis & FCC & 4 & $4.16 \mathrm{abc}$ & $0.31 \mathrm{ab}$ & $3.4 \mathrm{~cd}$ & & \\
\hline F. virginiana subsp. glacua & FVG & 2 & $0.90 \mathrm{a}$ & $0.13 \mathrm{a}$ & $2.4 \mathrm{~cd}$ & & \\
\hline F. virginiana subsp. platypetala & FVP & 4 & $8.82 \mathrm{bc}$ & $0.76 \mathrm{abc}$ & $4.0 \mathrm{e}$ & & \\
\hline F. virginiana subsp. virginiana (North) & FVVN & 6 & $11.72 \mathrm{~d}$ & $1.03 \mathrm{ab}$ & $3.3 \mathrm{~cd}$ & & \\
\hline F. virginiana subsp. virginiana (South) & FVVS & 6 & $1.92 \mathrm{ab}$ & $0.08 \mathrm{a}$ & $0.8 \mathrm{a}$ & & \\
\hline Genotype $^{v}$ & Taxon & $\mathrm{PI} \mathrm{NO}^{v}$ & $\mathrm{Rf}$ & $\begin{array}{l}\mathrm{Rf} \times \\
\text { Totem }\end{array}$ & $\begin{array}{c}\text { Gall } \\
\text { rating }\end{array}$ & $\begin{array}{c}\text { Root } \\
\text { tolerance }\end{array}$ & $\begin{array}{l}\text { Total plant } \\
\text { tolerance }\end{array}$ \\
\hline Camarosa & FA & & $0.01 \mathrm{a}$ & $0.00 \mathrm{a}$ & $0.0 \mathrm{a}$ & 0.55 & 1.04 \\
\hline NC95-21-1 & FVVS & 612569 & $0.01 \mathrm{a}$ & $0.00 \mathrm{a}$ & $0.0 \mathrm{a}$ & 0.79 & 0.83 \\
\hline NC $96-35-2$ & FVVS & 612323 & $0.02 \mathrm{a}$ & $0.00 \mathrm{a}$ & $0.0 \mathrm{a}$ & 0.85 & 1.02 \\
\hline Chandler & FA & & $0.04 \mathrm{a}$ & $0.00 \mathrm{a}$ & $0.0 \mathrm{a}$ & 0.90 & 0.82 \\
\hline Fred 9 & FVVN & 612493 & $0.14 \mathrm{a}$ & $0.01 \mathrm{a}$ & $0.0 \mathrm{a}$ & $0.70^{*}$ & 0.7 \\
\hline NC 95-19-1 & FVVS & 312486 & $0.15 \mathrm{ab}$ & $0.02 \mathrm{abc}$ & $0.1 \mathrm{a}$ & 0.83 & 0.95 \\
\hline Diamante & FA & & $0.32 \mathrm{ab}$ & $0.05 \mathrm{abc}$ & $1.5 \mathrm{bc}$ & 0.82 & 0.86 \\
\hline CFRA 24 & FCC & 236579 & $0.83 \mathrm{ab}$ & $0.13 \mathrm{abdc}$ & $0.7 \mathrm{ab}$ & $0.62^{*}$ & 0.96 \\
\hline Redcrest & FA & 551859 & 0.98 abc & $0.04 \mathrm{abc}$ & $0.4 \mathrm{a}$ & 0.88 & 0.92 \\
\hline MS 30-21 & FVVN & & $1.00 \mathrm{abcd}$ & $0.06 \mathrm{abdc}$ & $2.1 \mathrm{cde}$ & 0.68 & 0.86 \\
\hline CFRA 372 & FCC & 551736 & $1.18 \mathrm{abcd}$ & $0.07 \mathrm{abdc}$ & $3.8 \mathrm{ghi}$ & 0.66 & 0.90 \\
\hline Puget Reliance & FA & & $1.27 \mathrm{abcd}$ & $0.14 \mathrm{abdc}$ & $1.4 \mathrm{bc}$ & $0.71^{*}$ & 0.55 \\
\hline Honeoye & FA & 551588 & $1.56 \mathrm{abcd}$ & $0.06 \mathrm{abc}$ & $0.0 \mathrm{a}$ & 0.86 & 0.87 \\
\hline CFRA 338 & FVG & 551745 & $1.73 \mathrm{abcd}$ & 0.24 abcdef & $4.6 \mathrm{ijk}$ & 0.79 & 0.95 \\
\hline CFRA 1088 & FCPC & 612316 & $1.98 \mathrm{abcd}$ & 0.21 abcdef & $4.3 \mathrm{hijk}$ & $0.41^{*}$ & $0.73^{*}$ \\
\hline CFRA 42 & FCP & 551453 & $2.26 \mathrm{abcd}$ & 0.34 abcdefg & $2.0 \mathrm{~cd}$ & $0.33^{*}$ & $0.58^{*}$ \\
\hline CFRA 368 & FCP & 551735 & $2.28 \mathrm{abcd}$ & 0.18 abcdef & $3.5 \mathrm{fgh}$ & $0.49^{*}$ & $0.63^{*}$ \\
\hline MS 9-7 & FVVN & & $2.31 \mathrm{abcd}$ & 0.14 abcde & $3.0 \mathrm{efg}$ & 0.91 & $0.71^{*}$ \\
\hline CFRA 440 & FVP & 551794 & 8.52 cdefg & 0.83 fghij & $3.5 \mathrm{fgh}$ & $0.47 *$ & $0.54^{*}$ \\
\hline CFRA 1100 & FCPC & 602548 & $9.17 \mathrm{defg}$ & 0.97 ghij & $4.9 \mathrm{jk}$ & 0.75 & 1.14 \\
\hline Eagle 14 & FVVN & 612492 & $11.10 \mathrm{efgh}$ & 0.55 bcdefg & $4.9 \mathrm{jk}$ & $0.68^{*}$ & 0.87 \\
\hline HM1 & FCPC & 612489 & $11.46 \mathrm{efgh}$ & $1.49 \mathrm{j}$ & $4.0 \mathrm{hijk}$ & 0.80 & 0.88 \\
\hline CFRA 688 & FCPC & 612487 & $12.80 \mathrm{fgh}$ & 0.69 defghi & $4.3 \mathrm{hijk}$ & $0.50^{*}$ & 0.71 \\
\hline CFRA 796 & FCPC & 552091 & $13.60 \mathrm{fgh}$ & 0.73 efghi & $4.9 \mathrm{jk}$ & $0.54^{*}$ & 0.82 \\
\hline NAH 5-1 & FCC & & $13.66 \mathrm{fgh}$ & 0.72 efghi & $4.9 \mathrm{jk}$ & 0.79 & 0.88 \\
\hline CFRA 58 & FVP & 551471 & $15.19 \mathrm{gh}$ & $1.29 \mathrm{hij}$ & 4.4 hijk & 0.54 & 0.77 \\
\hline CFRA 34 & FCP & 551445 & $18.62 \mathrm{hi}$ & $1.33 \mathrm{ij}$ & 4.4 hijk & 0.50 & 1.01 \\
\hline RH 23 & FVVN & 612498 & $24.27 \mathrm{ij}$ & $2.56 \mathrm{k}$ & $4.9 \mathrm{jk}$ & 0.81 & $0.83^{*}$ \\
\hline Totem & FA & 551501 & $24.66 \mathrm{ij}$ & 1.00 ghij & $4.7 \mathrm{jk}$ & $0.95^{*}$ & $0.85^{*}$ \\
\hline RH 30 & FVVN & 612499 & $31.50 \mathrm{jk}$ & $2.84 \mathrm{k}$ & $5.0 \mathrm{k}$ & $0.54^{*}$ & 0.69 \\
\hline CFRA 1267 & FCP & 612488 & $33.88 \mathrm{k}$ & $2.80 \mathrm{k}$ & $5.0 \mathrm{k}$ & $0.57^{*}$ & 0.93 \\
\hline \multicolumn{8}{|l|}{ Significance $(P)$} \\
\hline Genotype & & & 0.001 & 0.001 & 0.001 & & \\
\hline Run $^{t}$ & & & 0.650 & 0.059 & 0.003 & 0.085 & 0.20 \\
\hline
\end{tabular}

${ }^{2} \mathrm{Rf}=$ final population density/initial nematode population density.

${ }^{y} \mathrm{Rf} \times$ Totem values are means of the Rf on plants of a genotype/Rf of 'Totem' in each replication.

${ }^{x}$ Gall rating $0=$ no galls, $1=1$ to 2 galls, $2=3$ to $10,3=11$ to $30,4=31$ to 100 , and $5=>100$ galls

"Values within a column followed by the same letter are not different according to Fisher's protected LSD $(P \leq 0.05)$.

${ }^{\vee}$ Sources of plant material; Plants with a PI (plant introduction) number are currently in the repository system, ORUS = selection from USDA-ARS (Corvallis, Ore.) program; MS = accession from University of Minnesota. NAH 5-1 was collected in the same community in Ecuador as NAH 3(PI 612318) and may be the same clone (Finn et al., 1998).

"Tolerance ratio value for a genotype is the mean of dry weights of tissues of infected plants/dry weights of tissues of noninfected plants in each replication. Asterisks indicate that dry weights of infected tissues differed $(P \leq 0.05)$ from tissues of noninfected plants.

tAnalysis of runs is only for the genotypes that were included in more than one run $(P \leq 0.05)$. 
Pratylenchus penetrans had less affect on root growth than did M. hapla (Table 2). Mean tolerance ratio value was 0.95 among all genotypes. Root growth was reduced by P. penetrans in four and increase in three genotypes $(P \leq$
0.05 ), while root biomass of other genotypes was not affected significantly by $P$. penetrans. Pratylenchus penetrans had little effect on total plant biomass with mean tolerance ratio value of 1.02 among genotypes.

\section{Discussion}

Dickstein and Krusberg (1978), Edwards et al. (1985) and Szczygiel (1981a) reported that $M$. hapla galled roots and/or reproduced

Table 2. Taxa and genotype means for reproductive factor $(\mathrm{Rf})^{\mathrm{z}}$, reproductive factor of genotypes compared to 'Totem', nematodes per gram root, and tolerance ratio values of root and total plant biomass of strawberry genotypes infected with Pratylenchus penetrans and noninfected control plants grown in greenhouse pots for 12 weeks.

\begin{tabular}{|c|c|c|c|c|c|c|c|}
\hline Species & Taxon & $\begin{array}{c}\text { No. of } \\
\text { genotypes }\end{array}$ & Rf & $\begin{array}{c}\mathrm{Rf} \times \\
\text { Totem }^{\mathrm{y}}\end{array}$ & $\begin{array}{c}\text { Nematodes/ } \\
\mathrm{g} \mathrm{root}^{\mathrm{x}}\end{array}$ & & \\
\hline Fragaria chiloensis subsp. pacifica & FCP & 6 & $0.76 \mathrm{~b}^{w}$ & $2.71 \mathrm{~b}$ & $582 \mathrm{e}$ & & \\
\hline F. chiloensis subsp. $f$. chiloensis & FCC & 4 & $0.19 \mathrm{a}$ & $0.86 \mathrm{a}$ & $83 \mathrm{ab}$ & & \\
\hline F. chiloensis f. patagonica subsp. chiloensis & FCPC & 4 & $0.32 \mathrm{a}$ & $1.41 \mathrm{a}$ & $268 \mathrm{~cd}$ & & \\
\hline F. virginiana subsp. glacua & FVG & 2 & $0.26 \mathrm{a}$ & $1.35 \mathrm{a}$ & $76 \mathrm{a}$ & & \\
\hline F. virginiana subsp. platypetala & FVP & 3 & $0.59 \mathrm{~b}$ & $2.86 \mathrm{~b}$ & 348 de & & \\
\hline F. virginiana subsp. virginiana (North) & FVVN & 5 & $0.26 \mathrm{a}$ & $1.52 \mathrm{a}$ & $97 \mathrm{ab}$ & & \\
\hline F. virginiana subsp. virginiana (South) & FVVS & 5 & $0.30 \mathrm{a}$ & $1.25 \mathrm{a}$ & $146 \mathrm{bc}$ & & \\
\hline F. ×ananassa & FA & 11 & $0.30 \mathrm{a}$ & $1.01 \mathrm{a}$ & $89 \mathrm{ab}$ & & \\
\hline Significance $(P)$ & & & 0.001 & 0.001 & 0.001 & & \\
\hline Genotype $^{v}$ & Taxon & $\mathrm{PI} \mathrm{NO}^{\mathrm{v}}$ & $\mathrm{Rf}$ & $\begin{array}{c}\text { Rf } \times \\
\text { Totem }\end{array}$ & $\begin{array}{l}\text { Nematodes/ } \\
\text { g root }\end{array}$ & $\begin{array}{c}\text { Root } \\
\text { tolerance }^{\mathrm{u}}\end{array}$ & $\begin{array}{l}\text { Total plant } \\
\text { tolerance }^{\mathrm{u}}\end{array}$ \\
\hline CFRA 372 & FCC & 551736 & $0.06 \mathrm{a}$ & $0.48 \mathrm{a}$ & $30.1 \mathrm{abc}$ & 0.88 & 0.95 \\
\hline Firecracker & FA & 617006 & $0.07 \mathrm{a}$ & $0.54 \mathrm{a}$ & $19.2 \mathrm{ab}$ & 0.91 & 0.69 \\
\hline CFRA 1092 & FCPC & 612317 & $0.08 \mathrm{a}$ & $0.48 \mathrm{a}$ & 35.7 abcde & 1.02 & $1.13^{*}$ \\
\hline Eagle 14 & FVVN & 612492 & $0.08 \mathrm{a}$ & $0.45 \mathrm{a}$ & $17.8 \mathrm{a}$ & 1.05 & 1.04 \\
\hline NAH 5-1 & FCC & & $0.09 \mathrm{a}$ & $0.74 \mathrm{abc}$ & $30.2 \mathrm{abc}$ & 0.98 & 0.87 \\
\hline Diamante & FA & & $0.09 \mathrm{a}$ & $0.43 \mathrm{a}$ & $18.4 \mathrm{ab}$ & $1.19^{*}$ & 1.28 \\
\hline ORUS 1414-1 & FA & & $0.10 \mathrm{ab}$ & $1.04 \mathrm{abcd}$ & $35.1 \mathrm{abcd}$ & 0.99 & 1.04 \\
\hline JP 95-1-1 & FVVS & 612570 & $0.13 \mathrm{abc}$ & 1.30 abcde & 104.2 defghi & 0.77 & 0.94 \\
\hline Scotts Creek & FCP & 612490 & $0.15 \mathrm{abc}$ & $2.00 \mathrm{abcdefgh}$ & $34.3 \mathrm{abcd}$ & 0.97 & 0.97 \\
\hline Allstar & FA & 551406 & $0.17 \mathrm{abcd}$ & $0.86 \mathrm{abcd}$ & $32.6 \mathrm{abcd}$ & 1.03 & 0.96 \\
\hline Chandler & FA & & 0.18 abcd & $0.60 \mathrm{ab}$ & $30.3 \mathrm{abc}$ & 1.12 & 0.93 \\
\hline ORUS 1484 & FCC & 616767 & 0.19 abcde & $0.82 \mathrm{abc}$ & 97.2 defghi & 0.95 & $1.24^{*}$ \\
\hline NC 96-5-3 & FVVS & 612325 & 0.19 abcde & $0.61 \mathrm{abc}$ & 80.0 cdefhgi & 0.87 & 1.00 \\
\hline MS 30-21 & FVVN & & 0.20 abcde & 1.78 abcdefg & $54.5 \mathrm{cdef}$ & $1.08^{*}$ & 1.05 \\
\hline NC95-21-1 & FVVS & 612569 & 0.21 abcdef & 1.43 abcde & 72.6 cdefg & 1.08 & $1.20^{*}$ \\
\hline MS 9-7 & FVVN & & 0.22 abcdef & 1.31 abcde & 44.8 bcdef & 1.01 & 1.11 \\
\hline CFRA 338 & FVG & 551745 & 0.23 abcdef & $1.08 \mathrm{abcd}$ & 76.9 cdefg & 1.08 & 1.28 \\
\hline NC 96-35-2 & FVVS & 612323 & 0.23 abcdef & $0.95 \mathrm{abcd}$ & 60.7 cdefg & 1.09 & $1.39^{*}$ \\
\hline Jewel & FA & & 0.28 abcdefg & $0.71 \mathrm{abc}$ & 74.8 cdefg & 0.81 & 0.98 \\
\hline LH 50-4 & FVG & 612495 & 0.30 abcdefg & 1.62 abcdef & 75.5 cdefg & 1.17 & $1.32^{*}$ \\
\hline CFRA 796 & FCPC & 552091 & 0.31 abcdefg & 2.46 bcdefgh & 186.2 ghijk & 1.02 & 1.10 \\
\hline Fred 9 & FVVN & 612493 & 0.32 abcdefg & 2.26 bcdefgh & 145.0 fghij & 0.79 & 0.97 \\
\hline CFRA 1100 & FCPC & 602548 & 0.32 abcdefg & 0.99 abcd & 100.1 defghi & 1.05 & $1.38^{*}$ \\
\hline Totem & FA & 551501 & 0.33 abcdefg & $1.00 \mathrm{abcd}$ & 95.4 cdefhgi & 1.05 & 0.99 \\
\hline Honeoye & FA & 551588 & 0.35 abcdefg & $1.17 \mathrm{abcd}$ & 62.6 cdefg & 1.09 & 1.04 \\
\hline CFRA 110 & FVP & 551527 & 0.36 abcdefgh & $3.79 \mathrm{~h}$ & 129.7 fghij & 0.93 & 0.91 \\
\hline CFRA 24 & $\mathrm{FCC}$ & 236579 & 0.41 bcdefgh & 1.38 abcde & 173.7 ghijk & 1.00 & 1.04 \\
\hline Camarosa & FA & & 0.46 bcdefghi & 1.46 abcde & 129.4 fghij & $1.17^{*}$ & $1.30^{*}$ \\
\hline RH 23 & FVVN & 612498 & 0.49 cdefghi & 1.81 abcdefg & 221.1 ghijk & 1.15 & 1.04 \\
\hline Redcrest & FA & 551859 & 0.51 defghi & 1.23 abcde & 183.9 ghijk & 0.97 & 1.00 \\
\hline CFRA 42 & $\mathrm{FCP}$ & 551453 & 0.54 efghi & 1.29 abcde & $501.4 \mathrm{klmn}$ & $0.64^{*}$ & 0.82 \\
\hline CFRA 688 & FCP & 612487 & 0.56 fghi & $3.75 \mathrm{~h}$ & $298.5 \mathrm{ijklm}$ & $0.60^{*}$ & 0.77 \\
\hline CFRA 1088 & FCPC & 612316 & $0.57 \mathrm{ghi}$ & 1.72 abcdef & $750.4 \mathrm{mn}$ & 1.09 & 0.82 \\
\hline CFRA 101 & FVP & 551518 & $0.69 \mathrm{hij}$ & $3.15 \mathrm{fgh}$ & 259.3 hijkl & 0.61 & 0.87 \\
\hline CFRA 58 & FVP & 551471 & 0.70 hijk & $1.65 \mathrm{abcdef}$ & $656.21 \mathrm{lmn}$ & 0.79 & 0.87 \\
\hline Puget Reliance & FA & & $0.76 \mathrm{ijk}$ & 2.04 abcdefgh & $295.8 \mathrm{ijkl}$ & 0.76 & 0.89 \\
\hline NC 96-48-1 & FVVS & 612324 & $0.76 \mathrm{ijk}$ & 1.98 abcdefgh & $413.8 \mathrm{jklm}$ & 0.77 & 0.90 \\
\hline HM1 & FCP & 612489 & $0.95 \mathrm{jk}$ & 2.82 defg & $470.6 \mathrm{klmn}$ & 0.97 & 1.14 \\
\hline CFRA 34 & FCP & 551445 & $1.02 \mathrm{kl}$ & 2.74 defg & $783.5 \mathrm{mn}$ & $0.57^{*}$ & 0.89 \\
\hline CFRA 1267 & FCP & 612488 & 1.321 & $3.66 \mathrm{gh}$ & $1404.1 \mathrm{n}$ & $0.83^{*}$ & 0.91 \\
\hline \multicolumn{8}{|l|}{ Significance $(P)$} \\
\hline Genotype & & & 0.001 & 0.001 & 0.001 & & \\
\hline Run $^{t}$ & & & 0.093 & 0.673 & 0.001 & 0.001 & 0.001 \\
\hline
\end{tabular}

${ }^{\mathrm{z}} \mathrm{Rf}=$ final population density/initial nematode population density.

' $\mathrm{Rf} \times$ 'Totem' values are means of the Rf on plants of a genotype/Rf of 'Totem' in each replication.

${ }^{x}$ Mean nematode densities per gram dry weight root was detransformed from $\log 10(\mathrm{x}+1)$ for statistical analysis.

"Values within a column followed by the same letter are not different according to Fisher's protected LSD $(P \leq 0.05)$.

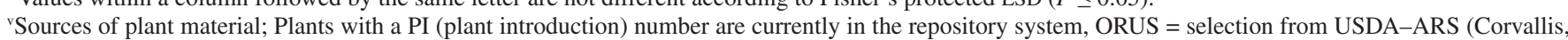
Ore.) program; MS = accession from University of Minnesota. NAH 5-1 was collected in the same community in Ecuador as NAH 3(PI 612318) and may be the same clone (Finn et al., 1998).

"Tolerance ratio value for a genotype is the mean of dry weights of tissues of infected plants per dry weights of tissues of noninfected plants in each replication. Asterisks indicate that dry weights of infected tissues differed $(P \leq 0.05)$ from tissues of noninfected plants.

${ }^{t}$ Analysis of runs is only for the genotypes that were included in more than one run $(P \leq 0.05)$. 
well on most strawberry cultivars tested, with several cultivars showing similar responses in different studies. Edwards et al. (1985) reported that 4 of 11 and Szczygiel (1981a) reported 2 of $25 F$. xananassa cultivars evaluated were resistant to M. hapla. We observed a high degree of resistance to $M$. hapla among a diverse collection of Fragaria genotypes, with $\operatorname{Rf}$ values $<0.5$ for 11 of the 44 genotypes tested. Of the $F$. xananassa cultivars evaluated in our study, 'Camarosa', 'Chandler', Allstar', Firecracker', and 'Dimante' were highly resistant to M. hapla. Orchard and Andrichem (1961) observed differential galling of roots among 11 Fragaria species and subspecies. They noted resistance in one genotype of $F$. virginiana subsp. platypetala. However, we observed no resistance in the four genotypes of $F$. virginiana subsp. platypetala or six genotypes of $F$. chiloensis f. patagonica subsp. chiloensis. Genotypes of the other taxa varied from resistant to highly susceptible. We expect that the variability in nematode resistance within a Fragaria taxon would increase in proportion to the number of populations of that taxon evaluated. Although plant genotypes may respond differentially to different populations of a species of plant-parasitic nematode (DeWaele and Elsen, 2002; Roberts, 2002), in the current research all but three Fragaria genotypes had similar levels of resistance to an Oregon and a Washington population of $M$. hapla. Our data suggest resistance to $M$. hapla in $F$. ×ananassa cultivars should be easily exploited by strawberry breeders.

Tolerance is more difficult to demonstrate than resistance. It is especially difficult in greenhouse pot experiments in which plant roots are confined in a small volume of soil, soil is infested with high densities of nematodes, and in which water and nutrients are not limiting. Most genotypes were intolerant to $M$. hapla and plants grown in infested soil had less root mass than those in noninfested soil. This reduction in root growth was observed even with genotypes that had few galls or did not support population increase of $M$. hapla. Second-stage juveniles (J2) that penetrated the roots may have adversely affected root growth, but were not able to establish feeding sites and develop further. The high infestation density, 5 eggs/g soil, may have exacerbated the damage to roots, even in resistant genotypes. For example, $M$ arenaria (Neal) Chitwood J2 penetrated resistant grape roots and caused hypersensitive reaction observed as necrosis of the root-tip (Anwar and McKenry, 2000). We observed that $M$. hapla affected the growth of roots more than total plant growth, i.e., among 44 genotypes the mean tolerance ratio value of total plant weight was 0.84 . In contrast, Edwards at al. (1985) reported that M. hapla reduced root and total plant biomass of $11 \mathrm{~F}$. xananassa cultivars to a similar degree.

Screening for host resistance and tolerance to migratory endoparasitic nematodes can be difficult compared to sedentary endoparasitic nematodes (DeWaele and Elsen, 2002; Peng and Moens, 2003). In our research, resistance of strawberry genotypes to $P$. penetrans was less common than resistance to $M$. hapla. The
Rf values for $P$. penetrans ranged from 0.06 to 1.32 , with the susceptible cultivar 'Totem' near the middle of the range at 0.33 . These $\mathrm{Rf}$ values were lower than reported by other researchers. Potter and Dale (1994) evaluated the susceptibility of 20 genotypes of $F$. virginiana and 13 genotypes of $F$. chiloensis 16 and 20 weeks after infestation, respectively. There was a high degree of variability between populations of each species, with estimated Rf values ranging from 0.2 to 3.7. 'Midway' which was a good host in a previous study (Szczygiel, 1981b) did not support $P$. penetrans reproduction as well in their study with an estimated $\mathrm{Rf}$ value $<0.39$. Infestation density, plant size at infection, experimental conditions and duration, nematode sampling and extraction methods, and variability of nematode inocula may explain the differences in the estimated $\mathrm{Rf}$ values observed between experiments (DeWaele ad Elsen, 2002). For example, the duration of our experiments was 2 to 6 weeks shorter and nematode extraction period was $7 \mathrm{~d}$ shorter than those in the Potter and Dale study (1994). As with other studies (Potter and Dale, 1994), we observed great variability and few significant differences in resistance of Fragaria genotypes to $P$. penetrans. By comparing each genotype to the susceptible 'Totem' in each replication, some of the variability in our study was removed. There were only two genotypes in common between previous and current research, but these data were consistent with our data. Pratylenchus penetrans reproduced well on 'HM1' in our research and that of Potter and Dale (1994), while 'Chandler' was a poor host in both studies (Dale and Potter, 1998). A susceptible cultivar, 'Honeoye', used by LaMondia $(1999,2002)$ in several studies had a similar degree of resistance to 'Totem' in our study. Our data support the conclusions of Potter and Dale (1994) that there is a good level of resistance to $P$. penetrans available in $F$. xananassa cultivars without resorting to wild genotypes. They also reported that certain genotypes from the University of California breeding program had resistance to P. penetrans (Dale and Potter, 1998). This was supported by the good degree of resistance that we observed with 'Diamante' and 'Chandler'. Our data should serve to rank cultivars, and wild genotypes, as candidates in breeding for resistance to $P$. penetrans.

The $\mathrm{Rf}$ values of genotypes were correlated $\left(R^{2}=0.67, P \leq 0.01\right)$ with $P$. penetrans per gram root tissue, which ranged from 18 to $1404 \mathrm{~g} /$ root. This range is similar to those observed on Fragaria genotypes and cultivars by other researchers (Goheen and Bailey, 1955; Kimpinski, 1985; LaMondia, 2002; Potter and Dale, 1994; Szczygiel, 1981b). Jaffee (1980) reported a negative correlation between root biomass at the time of infestation and the number of $P$. penetrans per gram root tissue. Genotypes of noninfected plants that produced the smallest root mass $(<70 \%$ mean mass of all genotype) had among the highest number of nematodes per gram root in infected plants in our study, i.e., CFRA 24, CFRA 42, CFRA 58, CFRA 101, CFRA 1088, CFRA 1267, HM1, and RH 23. Therefore, the rooting habit and structure of a genotype should be considered when interpreting the level of resistance based on nematodes in the root tissue.

Szczygiel (1981b) reported a reduction in total plant biomass of plants infected with $P$. penetrans compared to noninfected plants for most of the 28 strawberry cultivars evaluated. In contrast, $P$. penetrans significantly reduced root biomass of only four genotypes and did not reduce significantly whole plant biomass of any genotype in our research. Several factors may account for apparent high degree of tolerance observed in our study. Older, large strawberry plants propagated from runners, as were the plants used in our research, may be more tolerant than young plants (Szczygiel, 1986). Tolerance may be associated with the plant growth conditions that vary with season and environmental conditions. Szczygiel (1983) reported that tolerance of 'Senga Sengana' strawberry to $P$. penetrans was 160 nematodes/g soil in the spring and 35/g in the summer and autumn-winter. Goheen and Smith (1956) reported that growth differences between infected and control plants decreased as plants became pot bound, as was the case with vigorous genotypes in our study. Because of low infection density of $P$. penetrans in the roots of most genotypes, plants may have compensated partially for nematode parasitism. Screening strawberry genotypes for tolerance to nematodes under field conditions or in microplot experiments over several years (Dale and Potter, 1998; LaMondia, 1999) would be a more robust evaluation than greenhouse pot experiments (DeWaele and Elsen, 2002).

Most plant resistance has been developed to sedentary endoparasitic nematodes that have co-evolved a highly specialized relationship with the host (Roberts, 2002). Root-knot nematodes induce changes in the plant at the cellular level that result in the formation of a specialized feeding site, the giant cell. Resistance mechanisms that disrupt this process may rely on a single or few genes. Conversely, the development of plant resistance to less-specialized parasites, such as Pratylenchus spp. and ectoparasitic nematode species, has been more elusive. This is consistent with observation in our research. Eleven genotypes were highly resistant to both populations of M. hapla. Conversely, most genotypes were as susceptible to P. penetrans as 'Totem', a susceptible cultivar. Among the limited number of populations of Fragaria evaluated in this research, $F$. xananassa genotypes ranked among the most resistant to both nematode species. Integrating nematode resistance into horticulturally superior cultivars should be more rapid for $M$. hapla than for $P$. penetrans. In regions where $M$. hapla is a limiting factor to commercial production, this research identifies germplasm that is useful in developing resistance in breeding material. As several of the commercial cultivars showed good resistance to $M$. hapla and $P$. penetrans, there would be minimal value in returning to native germplasm as a source of resistance.

\section{Literature Cited}

Abu-Gharbiech, W., E.H. Verney, and W.R. Jenkins. 1962. Relationship of meadow nematode to 
verticillium wilt of strawberry. Phytopathology 52:921.

Anwar, S.A. and M.A. McKenry. 2000. Penetration, development, and reproduction of Meloidogyne arenaria on two new resistant Vitis ssp. Nematropica 30:9-17.

Ayoub, S. M. 1981. Plant nematology, an agricultural training aid. NemaAid Publ., Sacramento, Calif.

Brown, D.J.F., A. Dalmasso, and D.L. Trudgill, D.L. 1993. Nematode pests of soft fruits and vines, p. 427-462. In: K. Evans, D.L. Trudgill, and J.M. Webster (eds.). Plant parasitic nematodes in temperate agriculture. CAB Intl., Wallingford, U.K.

Clean Air Act. 1990. Title VI. Stratospheric ozone protection. Pub. L. 101-549. Section 6001. U.S. Congress, Wash., D.C.

Dale, A. and J.W. Potter. 1998. Strawberry cultivars vary in their reaction to northern lesion nematode. J. Nematol. 30:577-580.

De Waele, D. and A. Elsen. 2002. Migratory endoparasites: Pratylenchus and Radopholus species, p. 175-206. In: J.L. Starr, R. Cook, and J. Bridge (eds.). Plant resistance to parasitic nematodes. CAB Intl., Wallingford, U.K.

Dickstein, E.R. and L.R. Krusberg. 1978. Reaction of strawberry cultivars to the northern root-knot nematode, Meloidogyne hapla. Plant Dis. Rptr. 62:60-61.

Edwards, W.H., R.K. Jones, and D.P. Schmidt. 1985. Host suitability and parasitism of selected strawberry cultivars by Meloidogyne hapla and M. incognita. Plant Dis. 69:40-42.

Esnard, J. and B.M. Zuckerman. 1998. Small fruits, p. 685-725. In: K.R. Barker, G.A. Pederson, and G.L. Windham (eds.). Plant and nematode interactions. Amer. Soc. Agron., Madison, Wisc.

Finn, C.E., J.F. Hancock. and C. Heider. 1998. Notes on the strawberry of Ecuador: Ancient land races, the community of farmers and modern production. HortScience 33:583-587.

Food Quality Protection Act. 1996. Pub. L. 104-170, U.S. Congress, Wash., D.C.

Forge, T.A., R.E. Ingham, D. Kaufman, and J.N. Pinkerton. 2000. Population growth of Pratylenchus penetrans on winter cover crops grown in the Pacific Northwest. J. Nematol. $32: 42-51$.
Goheen, A.C. and J.S. Bailey. 1955. Nematodes in strawberry plantings in Massachusetts. Plant Dis. Rptr. 39:879-880.

Goheen, A.C. and J.B. Smith. 1956. Effects of inoculation of strawberry roots with meadow nematodes, Pratylenchus penetrans. Plant Dis. Rptr. 40:146-149.

Hancock, J.F., P.W. Callow, A. Dale, J.J. Luby, C.E. Finn, S.C. Hokanson, K.E. Hummer. 2001a. From the Andes to the Rockies: Native strawberry collection and utilization. HortScience 36:221-225.

Hancock, J.F., C.E. Finn, S.C. Hokanson, J.J. Luby, B.L. Goulart, K. Demchak, P.W. Callow, S. Serce, A.M.C. Schilder, and K.E. Hummer. 2001b. A multi-site comparison of native octoploid strawberries from North and South America. J. Amer. Soc. Hort. Sci. 126:579-586.

Hancock, J.F., S.C. Hokanson, C.E. Finn, and K. Hummer. 2002. Introducing a supercore collection of wild octoploid strawberries. Acta Hort. 567:77-79.

Hussey, R.S. and K.R. Barker. 1973. A comparison of methods of collecting inocula of Meloidogyne ssp., including a new technique. Plant Dis. Rptr. 57:1025-1028.

Jaffee, B.A. 1980. Influence of root biomass on number of Pratylenchus penetrans within host roots. Phytopathology 70:1212-1216.

Kimpinski, J. 1985. Nematodes in strawberries on Prince Edward Island, Canada. Plant Dis. 69:105-107.

Kurppa, S. and T.C. Vrain. 1989. Effects of Pratylenchus penetrans on the infection of strawberry roots by Gnomonia comari. J. Nematol. 21:511-516

Martin, S.B. 1988. Identification, isolation frequency, and pathogenicity of anastomosis groups of binucleate Rhizoctonia spp. from strawberry roots. Phytopathology 78:379-384.

LaMondia, J.A. 1999. Effects of Pratylenchus penetrans and Rhizoctonia fragaraie on vigor and yield of strawberry. J. Nematol. 31:418-423.

LaMondia, J.A. 2002. Seasonal populations of Pratylenchus penetrans and Meloidogyne hapla in strawberry roots. J. Nematol. 34:409-413.

Orchard, W.R. and M.C.J. Andrichem. 1961. Relative susceptibility of Fragaria ssp. to the root- knot nematode, Meloidogyne hapla Chitwood. Plant Dis. Rptr. 45:308

Peng, Y. and M. Moens. 2003. Host resistance and tolerance to migratory plant-parasitic nematodes. Nematology 5:145-177.

Potter, J.W. and A. Dale. 1994. Wild and cultivated strawberries can tolerate or resist root-lesion nematode. HortScience 29:1074-1077.

Roberts, P. A. 2002. Concepts and consequences of resistance, p. 23-41. In: J.L. Starr, R. Cook, and J. Bridge (eds.). Plant resistance to parasitic nematodes. CAB Intl., Wallingford, U.K.

Szczygiel, A. 1981a. Trials on susceptibility of strawberry cultivars to the northern root-knot nematode, Meloidogyne hapla. Fruit Sci. Rpt. 8:115-119.

Szczygiel, A. 1981b. Trials on susceptibility of strawberry cultivars to the root lesion nematode, Pratylenchus penetrans. Fruit Sci. Rpt. 8:121-125.

Szczygiel, A. 1983. On the tolerance limit of strawberry plants to root lesion nematode Pratylenchus penetrans (Cobb). Fruit Sci. Rpt. 10:135-143.

Szczygiel,A. 1986. Effect of Pratylenchus penetrans and Longidorus elongatus on strawberry plants as influenced by host age at inoculation. Fruit Sci. Rpt. 13:31-37.

Szczygiel, A. and H. Profic-Alwasiak. 1989. Studies on the interaction between nematodes and fungi infecting strawberry plants. Acta. Hort. 265:561-568.

Taylor, A.L. and J.N. Sasser. 1978. Biology, identification and control of root-knot nematodes (Meloidogyne spp.). Dept. Plant Pathol., N.C. State Univ.-U.S. Agency Intl. Dev., Raleigh, N.C.

Townshend, J.L. 1963a. The pathogenicity of Pratylenchus penetrans to strawberry. Can. J. Plant Sci. 43:75-78

Townshend, J.L. 1963b. A modification and evaluation of the apparatus for the Oostenbrink direct cottonwool filter extraction method. Nematologica 9:106-110.

Young, L.D. 1998. Breeding for nematode resistance and tolerance, p 187-208. In: K.R. Barker, G.A Pederson, and G.L. Windham (eds.). Plant and nematode interactions. Amer. Soc. Agron. Madison, Wisc. 